\title{
The Effectiveness of Kesum Leaves (Polygonum Minus) in Reducing of Free Fatty Acids in Used Cooking Oil
}

\author{
Gervacia Jenny.R ${ }^{1, * a}$ and Ratih Indrawati ${ }^{2, b}$ \\ ${ }^{1}$ Health Analysis Department, Poltekkes Kemenkes Pontianak, Jalan Dr. Sudarso, Pontianak, Indonesia \\ ${ }^{2}$ Health Analysis Department, Poltekkes Kemenkes Pontianak, Jalan Dr. Sudarso, Pontianak, Indonesia \\ *,a Corresponding Author: prodi_d4analis@yahoo. \\ b indrawati.haykal@gmail.com
}

\begin{abstract}
This study aims to determine the effect of adding Kesum leaves (Polygonum Minus) to used cooking oil on reducing levels of free fatty acids. This type of research is quasi experimental. The population in this study is used cooking oil and the sample used is used cooking oil that has been added with the leaves of Kesum with 5 treatments and replicated 5 times so that the total sample is 25 . From the results, it was found that the average reduction in free fatty acid levels in used cooking oil before adding the leaves of Kesum was $7,12 \%$, which had added Kesum leaves as much as 20 grams of $6.93 \%$, 40 grams of $5.36 \%$, 60 gr at $3.93 \%, 80$ gr at $3.26 \%$ and 100 gr at $1.62 \%$. The results of the analysis using linear regression test, it is known that the addition of 20 grams and $\mathbf{4 0}$ grams of $p$-value is $\mathbf{0 . 0 2 6}$ and $\mathbf{0 . 0 2 1}$ $(p<0.05)$, respectively, therefore, Ha is accepted, that is, there is a relationship between the effectiveness of leaves of Kesum (Polygonum Minus) in reducing levels of fatty acid numbers. free of used cooking oil, namely the addition of 20 and 40 grams. Whereas in the addition of 60,80 and 100 grams of Kesum leaves there was no relationship that was shown with a $p$ value $>0.05$.
\end{abstract}

Keywords-Polygonum Minus, Free Fatty Acid, Used Cooking Oil.

\section{Introduction}

The Kesum plant (Polygonum Minus) is one of the potential biological wealth of West Kalimantan. This plant is spread in West Kalimantan and is widely known by the community. Kesum leaves are used as a complement to food such as spicy porridge. This utilization is because the Kesum gives a delicious aroma, distinctive taste and delicious [1].

Based on the previous research, the leaves of Kesum have high antioxidant activity because it contains a high enough total phenolic compounds which can stop free radical reactions [2].

A free radical is any atom or molecule that has one or more unpaired electrons. Free radicals are considered dangerous because they are unstable and become very reactive in an attempt to gain an electronic partner, causing the formation of new radicals. Free radicals interfere with the integrity of cells because they can react with cell components. The formation of these new radicals can cause damage to various components of body cells such as DNA, and can also cause lipid peroxidation. To avoid these reactions in the body, we need an important compound that can stop or inhibit free radical reactions, namely antioxidants.

Antioxidants are molecules that can slow down or prevent the oxidation process of other molecules. Antioxidants are ingredients that help protect body cells from the harmful effects of free radicals. Antioxidants are electron donors or resultants. Antioxidant compounds have a small molecular weight, but are able to inactivate the development of oxidation reactions by preventing the formation of radicals. Antioxidants are also compounds that can inhibit oxidation reactions by binding to free radicals and highly reactive molecules [3].

Antioxidants can come from various natural sources or be synthesized in the laboratory. Synthetic antioxidants BHA (Butylated hydroxyl anisole), BHT (Butylated hydroxyt Toluene), PG (Propyl Gallate) and TBHQ (ter-butyl hydroquinone) are often used to control the occurrence of oxidation. However, it does not rule out that these antioxidants cause carcinogenic effects. Natural antioxidants are safer for consumption and more easily absorbed by the body than synthetic antioxidants [4].

Free radicals can be obtained naturally and from outside the body. Naturally, free radicals are chemicals that are produced from the process of digesting food. Meanwhile, from outside the body, caused by cigarette smoke and radiation. Many sources of free radicals are bound: chemicals in food, heated unsaturated fats, margarine and other unsaturated fatty acids. The repeated use of cooking oil is one of the factors causing the emergence of free radicals in oil. Oil damage that 
occurs during the frying process includes oxidation, polymeration, and hydrolysis. In used cooking oil that has been damaged, it will form unwanted compounds such as polymer compounds, free fatty acids (ALB), peroxides and other impurities suspended in the oil.

The deterioration of oil is accelerated by the presence of water from fried foods. During the frying process, oil in high temperature conditions comes into contact with air and water in the ingredients. The water in the ingredients will evaporate and the cooking oil will enter the ingredients to replace the ingredients. This incident causes the oil to be absorbed in the material and the oil undergoes hydrolysis which decides the fatty acids so that the oil can suffer damage which is indicated by the increase in the free fatty acid (ALB) content [5].

Research on the reduction of acid numbers in used cooking oil using bagasse as an adsorbent was conducted by [6]. The results showed that the reduction in the acid number of used cooking oil by soaking bagasse for $2 \times 24$ hours was $0.0999 \%$. Meanwhile, research that has been done used $50 \mathrm{ml}$ noni juice to reduce the free fatty acid number in used cooking oil and obtained a decrease of $24.68 \%$ [7].

\section{Research Methodology}

This research design used in this study was Quasi Experiment [8].

\section{A. Material}

The material used in this study is the leaves of Kesum which have been dried in an oven and then mashed using a blender and then then filtered using a mesh filter.

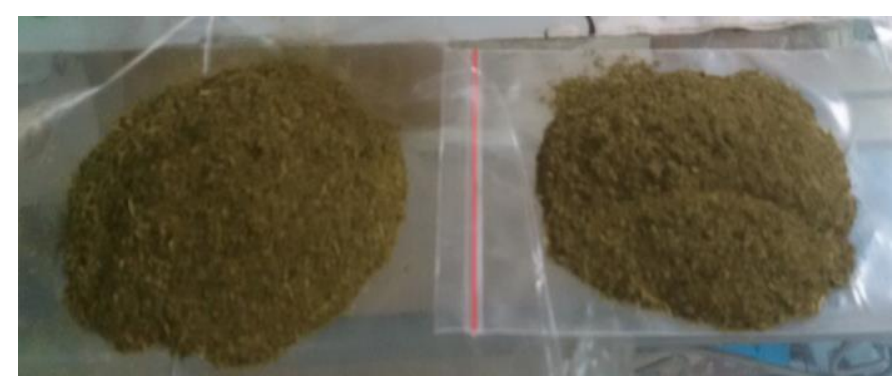

\section{B. Method}

Examination Method Measurement and examination of free fatty acid levels in used cooking oil is an alkalimetric method. Principles of Examination Titration of samples dissolved with neutral alcohol by sodium hydroxide $(\mathrm{NaOH})$ to neutralize free fatty acids in the sample.

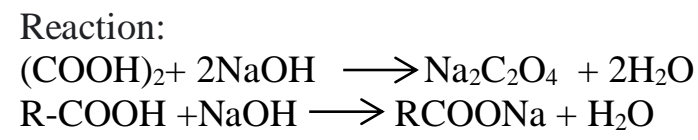

The cooking oil is stirred evenly and cultivated in a liquid state so that it is easy to take. The sample was weighed as much as $10-20 \mathrm{~g}$ and put into a $250 \mathrm{ml}$ Erlenmeyer flask. To the sample, $50 \mathrm{ml}$ of hot neutral alcohol and $2 \mathrm{ml}$ of phenolphthalein (PP) indicator were added to the sample and then immediately titrated using $0.100 \mathrm{~N} \mathrm{NaOH}$ until a color change occurred from colorless to pink which did not disappear for 30 seconds. Free fatty acids are expressed as percent free fatty acids which are calculated using the following equation: $\%$ free fatty acids $=\times 100 \%$ Acid number. The acid number is the number of milligrams of $\mathrm{KOH}$ needed to neutralize 1 gram of sample. The Acid Number is calculated from the $\%$ value of free fatty acids using the equation [9]:

\section{$\%$ Free Fatty Acid $=$ \\ $\frac{V \mathrm{NaOH}(\mathrm{ml}) \times \mathrm{N} \mathrm{NaOH} \times \text { molecul weight of fatty acid }}{\text { Sample weight }(\mathrm{gr})} \times 100 \%$}

\section{Results and Discussion}

Table 1 is Descriptive Statistical Test on Used Cooking Oil before and after adding the leaves of Kesum.

Table 1. Descriptive Statistics

\begin{tabular}{|c|r|r|r|r|r|}
\hline & N & Min & Max & Mean & $\begin{array}{c}\text { Std. } \\
\text { Deviation }\end{array}$ \\
\hline 0 gram & 5 & 6.54 & 8.00 & 7.1200 & .56040 \\
20 gram & 5 & 6.42 & 7.85 & 6.9320 & .57186 \\
40 gram & 5 & 4.57 & 6.87 & 5.3620 & .89069 \\
60 gram & 5 & 2.64 & 4.82 & 3.9260 & .83197 \\
80 gram & 5 & 1.57 & 4.10 & 3.2600 & .99048 \\
100 gram & 5 & 1.12 & 2.29 & 1.6180 & .46800 \\
Valid N (listwise) & 5 & & & & \\
\hline
\end{tabular}

Based on table 1, it can be seen that the highest decrease in used cooking oil with added Kesum leaves as much as $100 \mathrm{gr}$ is $1.12 \%$ with an average of $1.62 \%$ and the lowest decrease is in used cooking oil added with leaves of Kesum as much as $20 \mathrm{gr}$ is $7,85 \%$ with an average of $6.9 \%$. 
To investigate the relationship between the additions of Kesum leaves to free fatty acids in used cooking oil, it was tested with a correlation test and the following results were obtained:

Table 2. The relationship of the addition of leaves of Kesum to free fatty acids in used cooking oil

\begin{tabular}{ccccccc}
\hline & \multicolumn{6}{c}{ Addition of Kesum Leaves } \\
\cline { 2 - 7 } & $\mathbf{0} \mathbf{~ g r}$ & $\mathbf{2 0} \mathbf{~ g r}$ & $\mathbf{4 0} \mathbf{~ g r}$ & $\mathbf{6 0} \mathbf{~ g r}$ & $\mathbf{8 0} \mathbf{~ g r}$ & $\mathbf{1 0 0} \mathbf{~ g r}$ \\
$\begin{array}{c}\text { Pearson } \\
\text { Correlation }\end{array}$ & & 0,922 & 0,932 & 0,624 & 0,452 & 0,311 \\
Sig. (2-tailed & & 0,026 & 0,021 & 0,260 & 0,445 & 0,611 \\
\hline
\end{tabular}

Based on the data above, it was found that the strength of the relationship between free fatty acids in used cooking oil before adding Kesum leaves and free fatty acids in used cooking oil after adding 20 gr of Kesum leaves obtained a value of $r=0.922$ and $p$ value $=0.026$, after the addition of 40 gr the value was obtained. $r=0.932$ and $p$ value $=0.021$, after the addition of 60 gr leaves of Kesum, the value of $r=0.624$ and $\mathrm{p}$ value of 0.260 was obtained, after the addition of 80 gr leaves of Kesum, the value of $r=0.452$ and $p$ value $=0.445$, and after the addition of $100 \mathrm{~g}$ of Kesum leaves gr obtained value $r=0.311$ and $p$ value $=0.611$.

Based on the results of the study, there was a decrease in free fatty acid levels in used cooking oil which was added with Kesum leaves weighing 20, 40, 60,80 , and 100 grams, respectively. However, statistically it turns out that only the addition of Kesum leaves as much as 20, 40 grams which shows a relationship between the effectiveness of leaves of Kesum (Polygonum Minus) in reducing the levels of free fatty acids in used cooking oil, namely the value of $p$ $<0.05$ is obtained. In the addition of 60,80 and 100 grams of Kesum leaves, the value of $p<0.05$ was obtained which showed that there was no relationship between the addition of Kesum leaves in reducing the levels of free fatty acids in used cooking oil.

\section{Conclusion}

The conclusions of this study are:

1. The average free fatty acid content of used cooking oil before and after adding the leaves of Kesum as much as 20,40, 60, 80 and 100 grams, respectively, is $7.12 \%, 6.93 \%, 5.36 \%, 3.92 \%, 3.26 \%$ and $1.62 \%$.

2. The results of computerized data processing through the Correlation test of adding 20 grams of Kesum leaves obtained a value of $r=0.922$ and a value of $p$ $=0.026$, an addition of 40 grams obtained a value of $r$ $=0.932$ and a value of $p=0.021$, the addition of 60 grams obtained a value of $\mathrm{r}=0.624$ and $\mathrm{p}$ value $=$ 0.260 , the addition of 80 grams obtained the value of $r=0.452$ and the value of $p=0.445$ and the addition of 100 grams obtained the value of $r=0.311$ and the value of $p=0.611$. So it can be concluded that $\mathrm{Ha}$ is accepted, that is, there is a relationship between the addition of 20 and 40 grams of Kesum leaves on free fatty acid levels in used cooking oil with a $\mathrm{p}$ value $<0.05$. Whereas the addition of 60,80 and 100 grams of Kesum leaves there was no relationship between the addition of leaves of Kesum to the levels of acid numbers with a value of $p>0.05$.

\section{Acknowledgement}

We would like to thank to the Director of Poltekkes of the Ministry of Health in Pontianak, Head of the Pontianak Health Analyst Department and friends and lecturers at the Pontianak Health Analyst Department who have provided guidance, assistance, support and motivation in writing this journal and thank also for the all team of enumerators who have helped the completion of this research.

\section{References}

[1] M. A. Wibowo, 2007. "Uji antimikroba fraksi metanol dan dietil eter daun tanaman Kesum, (Antimicrobial test of the methanol and diethyl ether fraction of the leaves of the Kesum plant)" Agripura, Vol. 3, No. 2, pp. 410-414.

[2] M. A. Wibowo, M. S. Anwari, and R. Aulanni'am, 2009. "Skrinning Fitokimia Fraksi Methanol, Dietileter dan nHeksana Ekstrak Daun Kesum (Polygonum Minus),(Phytochemical Screening of Methanol, Diethyleter and n-Hexane Fraction of Kesum Leaf Extract (Polygonum Minus))" J. Penelit. Univ. Tanjungpura, Vol. 16, No. 4, pp. 5460.

[3] H. Winarsi, 2005. Antioksidan alami dan radikal, (Natural antioxidants and radicals). Kanisius.

[4] OD.+ R. =\$\%. D.L. (Madhavi,(1\$.S. Deshpande, 1995. Food Antioxidants Technological: Toxicological and Health Perspectives", 1st Editio. CRC Press.

[5] B. Budiyanto, M. Zuki, and M. S. Hutasoit, 2012. "Ketahanan Minyak Goreng Kemasan dan Minyak Curah pada Penggorengan Kerupuk Jalin (The resistance of packaged cooking oil and bulk oil in interlaced cracker frying)," $J$. Agroindustri, Vol. 2, No. 1, pp. 34-40.

[6] A. F. Ramdja, L. Febrina, and D. Krisdianto, 2010. "Pemurnian Minyak Jelantah Menggunakan Ampas Tebu Sebagai Adsorben, (Used Used Oil Purification Using Sugarcane Dregs as Adsorbent)" J. Tek. Kim., Vol. 17, pp. 7-14.

[7] Muh. Irwan et.al, 2010. "Regenerasi Minyak Jelantah (Waste cooking Oil)) Dengan Penambahan Sari Mengkudu, (Regeneration of Used Cooking Oil with the addition of Noni juice)" Vol. 10, No. 1. 
[8] P. D. Sigiyono, "Metode Penelitian Kuantitatif Kualitatif dan R\&D.pdf, (Qualitative and Quantitative Research Methods and R \& D)" 10th ed., Bandung: Alfabetha Bandung, 2010.

[9] D. S. Sopianti, H. T. Saputra, and A. F. A. Bengkulu, "Penetapan kadar asam lemak bebas pada minyak goreng, (Determination of free fatty acid levels in cooking oil)" $J$. Katalisator, Vol. 2, No. 21, pp. 100-105, 2017. 